Hussaini Ojagefu Adamu* , Rahimat Oshuwa Hussaini, Cedric Obasuyi, Linus Irefo Anagha, Gabriel Oscy Okoduwa

\title{
Prevalence of mastitis in Nigerian livestock: a Review
}

https://doi.org/10.1515/ovs-2020-0101

Received July 06, 2020; accepted August 27, 2020

\begin{abstract}
Mastitis is a disease of livestock that directly impede livestock production and thus hindering the socio-ecological development of sub-Saharan Africa. Studies have estimated the prevalence of this disease in $30 \%$ of Africa countries, with Ethiopia having the highest prevalence. The coverage is low, despite the wide livestock and dairy farms distribution in Africa. Furthermore, estimated economic losses due to the impact of mastitis are lacking in Nigeria. The disease is endemic in Nigeria as indicated by the available data and there are no proposed management plans or control strategies. This review is thus presented to serve as a wakeup call to all parties involved to intensify efforts towards the diagnosis, control, and management of the disease in Nigeria.
\end{abstract}

Keywords: Mastitis, Livestock, somatic cell count, Nigeria

\section{Introduction}

Mastitis is the inflammation of the parenchyma in the mammary gland of livestock. The disease is endemic and can affect all lactating animals [1]. The Most isolated pathogens include Staphylococcus spp, Streptococcus spp, E. coli, and Pasteurella spp [2]. The impact of mastitis on a community is as a result of the complex interplay between management practice and infectious agents, in addition to other factors,

\footnotetext{
*Corresponding author: Hussaini Ojagefu Adamu, Faculty 02 Biology/Chemistry, University of Bremen, Bremen, 28359, Germany

Rahimat Oshuwa Hussaini, Linus Irefo Anagha, Gabriel Oscy Okoduwa, Department of Zoology, Faculty of Life Sciences, Ambrose Alli University, Edo State, 300271, Nigeria Cedric Obasuyi, Department of Microbiology, Faculty of Life Sciences, University of Benin, Edo State, 300271, Nigeria
}

such as genetics, udder shape, or climate. [3, 4]. Recently, it was estimated that Nigeria has 18.4 million cattle, 76 million goats, 43.4 million sheep with relative numbers of cattle used for beef and milk production amounting to 3.38 million and 2.27 million heads respectively [5]. However, the majority of this livestock is at risk of mastitis because of the milking procedure and the unhygienic housing conditions. The economic impact of the disease is greatly influenced by direct and indirect losses. Depending on the severity of the disease, mastitis causes significant economic losses to the dairy industry in terms of reduced milk production and quality, an increased risk of culling of infected animals, increased veterinary costs and deaths $[6,7]$ Mastitis can be classified as clinical or subclinical. In infected animals, clinical mastitis shows signs of inflammation such as redness, heat, pain, and swollen udder [8]. Additionally, there are visible deformities in the milk like clots, abnormal color, flakes, and blood [9]. Sub-clinical mastitis does not show visible signs but is commonly noticed by elevation of somatic cell count (SCC) by California Mastitis Test (CMT). Generally, the programs for controlling mastitis are lacking, meanwhile the knowledge and awareness of risk factors and attributes of mastitis-causing pathogens are paramount to control the widespread of the disease at the farm level. However, the application of SCC as a means of milk quality control and udder health in industrialized countries has increased, this method is yet to be adopted in many countries in the tropics [7]. In Nigeria and most of the developing countries, there is a lack of information on the economic impact of the disease, lack of awareness among farmers concerning sub-clinical mastitis and the importance of udder health, and lack of a specific national program to control mastitis. Thus, it is imperative to regularly appraise the status of the disease so as to present holistic data to plan a control or management program as presented for Nigeria in this report. 


\subsection{Location and environment}

Nigeria has an area of $923,768 \mathrm{~km}^{2}$ with 36 states and the Federal Capital Territory (FCT), Abuja. These states are further grouped into six geopolitical zones (North-West, North-East, North-Central, South-East, South-South, and South-West) (see Fig. 1). The pattern in the rainfall received by various states is such that the north receives less rainfall with a shorter wet season than the south. Also, Nigeria can be zoned latitudinally into Guinea (South: $8^{\circ} \mathrm{N}$ ) [Lagos, Oyo, Ekiti, Osun, Ondo, Edo, Delta, Bayelsa, Abia, Ebonyi, Anambra, Rivers, Imo, Enugu, Cross River, Akwa Ibom states]; Savanna [Plateau, Kaduna, Bauchi, Kwara, Niger, Nasarawa, Taraba, Adamawa, Gombe, Benue and Kogi state and Abuja $\left(8-11^{\circ} \mathrm{N}\right)$; and Sahel (farther North: $\left.11-16^{\circ} \mathrm{N}\right)$ [Kebbi, Sokoto, Zamfara, Kastina, Kano, Jigawa, Borno, Gombe, and Yobe states] [10]. The annual rainfall ranges from 1400 to $2700 \mathrm{~mm}$ in the Guinean zone, 950- 1400 $\mathrm{mm}$ (Savanna zone), and 450-1050 mm (Sahelian zone) [11]. The rainfall pattern is monomodal for Savanna and Sahel and bi-modal for Guinea. In April, there is sufficient rainfall that marks the start of agriculture activities in Nigeria peaking between August and September in Sahel and Savanna; while in Guinea, the first peak is in July followed by a short break in August, then the second peak in September. The dominant vegetation types range from the dense mangroves of the Niger Delta and the rain forest of the south to the dry grassland of the north. Nigeria's climatic and environmental conditions predispose to the spread of mastitis.

Several species of common bacteria, fungi, mycoplasmas, and algae cause mastitis meanwhile mastitis due to bacterial pathogens accounts for most cases [12]. Mastitis pathogens are grouped as contagious or environmental [13]. The Contagious forms such as Staphylococcus aureus, Streptococcus agalactiae, Mycoplasma spp, and Corynebacterium bovis live and multiply on and in the cow's mammary gland and are spread from cow to cow during milking [14]. Environmental mastitis is an intra-mammary infection (IMI) caused by pathogens whose primary reservoir is the environment in which the cow lives [15]. Some of the well-known environmental isolated mastitis pathogens include Streptococci uberis and Streptococci disgalatiae. Also, some gram-negative bacteria like Esherichia coli, Klebsiella spp, and Enterobacter spp are environmentally isolated [16].

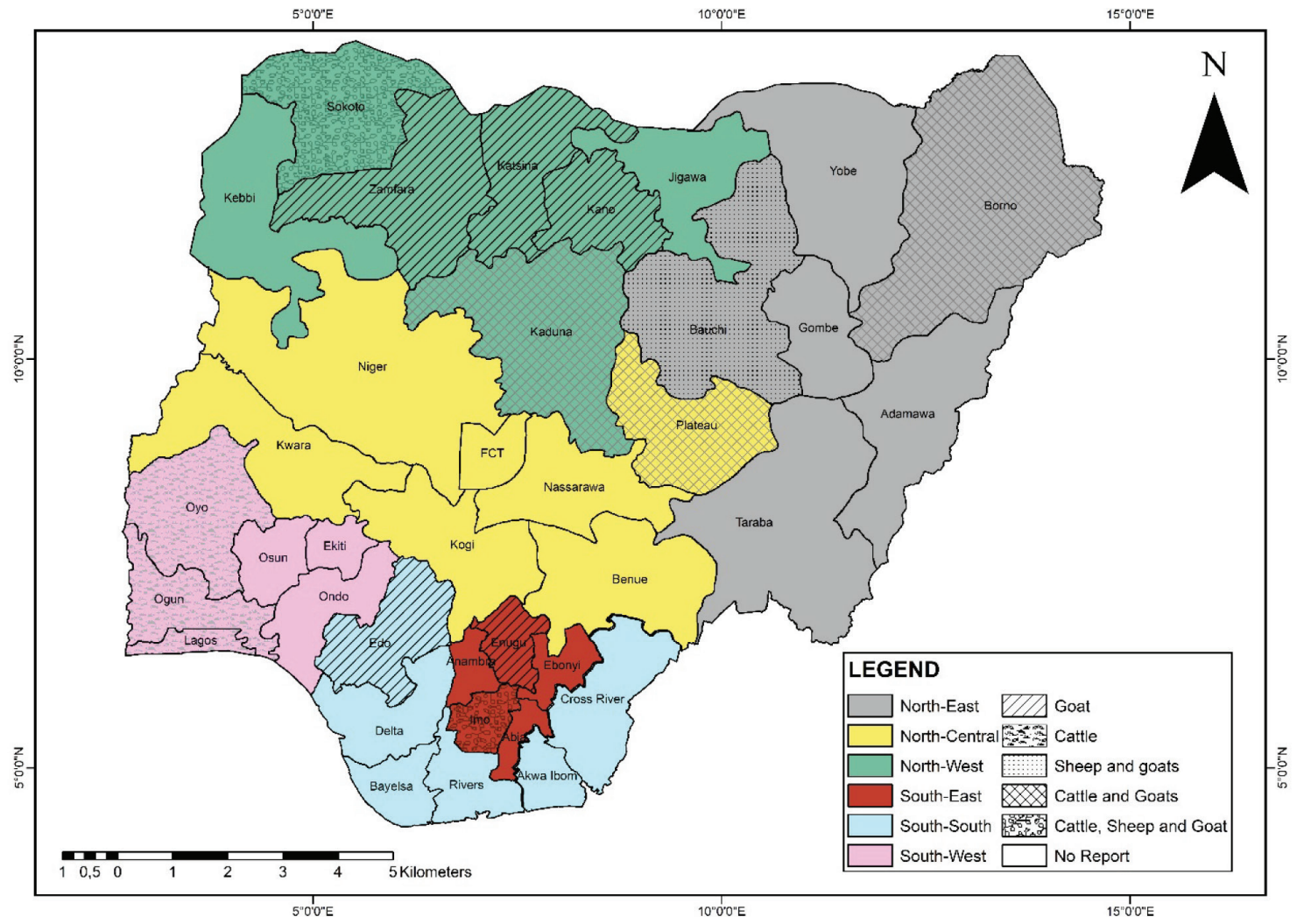

Figure 1 Map of Nigeria indicating areas of Mastitis survey on livestock 
Mycoplasma species show some differences in transmission, thus a brief discussion is warranted. Mycoplasma is responsible for many diseases in cattle, including respiratory disorders, otitis media, arthritis and mastitis. Mycoplasma was first isolated from mastitic cows in the USA in 1961, originally named Mycoplasma agalactiae var. bovis due to the similarities in biochemical, immunological and genetic features it shares with the small ruminant pathogen $M$. agalactiae [17]. Among the 200 species of Mycoplasma discovered to date, M. bovis, M. arginine, M. dispar, M. canadense, M. bovoculi, and Mycoplasma spp bovine groups 7 and F-38 have been reported to be involved in bovine mastitis [13, 18]. Mastitis caused by mycoplasma is less common than those caused by other bacteria, and it has been implicated in causing severe udder disease and has a distinct epidemiology accompanied with a peculiar set of risk factors [19]. However, in Nigeria Egwu et al. [20] reported mycoplasma mastitis in goat, species identified includes M. agalactiae, M. capriolum, M. mycoides, and M. bovis. The treatment for this form of mastitis is unrewarding due to the following reasons: Firstly, mycoplasmas are resistant to penicillin and cephalosporins. Secondly, over the last two decades, in vitro resistance to all the main antibiotic classes including fluroquinolones has been detected in $M$. bovis isolates and this explains the lack of impact of these antibiotics in vivo [21]. Thirdly, mycoplasmas are known to infect different body sites, hence treatment is rarely thorough as this characteristic enables their survival. Finally, the ability of mycoplasmas to invade host cells and form biofilms as well as the lack of cell wall has allowed them to evade antibiotic therapy [22]. Based on field experience, most investigators have concluded that antibiotic therapy of mycoplasma mastitis is not an economically viable control strategy.

Similarly, the development of mycoplasma vaccines has not yielded any promising prospects since the organism has the ability to evade the host by altering their surface proteins and inducing immunomodulatory effects [23]. However, vaccines aimed mainly at the pneumonic form of the disease are available in the USA and UK but there is little published evidence of their efficacy, especially for mastitis [24, 25].

The role of the season in the incidence of mastitis has been studied. The prevalence of mastitis varies from season to season since the growth and multiplication of organisms depends on specific temperature and humidity. Inadequate ventilation, with high temperature and relative humidity, encourages the proliferation of various bacteria. The exposure of livestock to high temperature induces stress and subsequently altering the immune functions [26]. In India, Joshi and Gokale [27] reported that animals are more vulnerable to Subclinical mastitis (SCM) in the monsoon season compared to summer or winter. Also, in Ethiopia, Dego and Tareke [28] reported a higher occurrence in the rainy season than in the dry season. In Nigeria, a 5-year study by Kawu et al. [29] reported that the peak occurrence of clinical mastitis (CM) in goats coincides with the hot dry to the early wet season. Similarly, Okoli et al. [30] noticed a high prevalence among cattle and goats in the late dry season while in sheep during the early rainy season. Very few surveys (with varying results) on the seasonal prevalence of mastitis have been documented for Nigeria in Imo state (South-East) and Zaria, Kaduna state (North-West) [29, 30]. Clearly, data in this regard are lacking in most part of Nigeria; hence the need for a comprehensive national survey as this would ensure an updated seasonal disease burden for effective execution of a mastitis-control program.

\subsection{Mastitis in livestock}

The livestock sub-sector is a key and essential constituent of Nigeria's agriculture, known to be the main source of household wealth and food security [31]. It contributes around 1.7 percent to the national GDP and around 9 percent to the agriculture value added [32]. Furthermore, Nigeria is noted to be one of the four leading livestock producers in Sub-Sahara Africa. The prevalence of clinical and sub-clinical mastitis in livestock has been reported for many regions of the world. However, most reports come from developed countries, some of which are by Bradley [33] and Petrovski et al. [34] In Africa, the disease occurrence is well documented in $30 \%$ of countries [25]. The economic impact of mastitis including annual losses estimated per cow has been documented in the USA and EU [35, 36]. The lack of published materials in Africa greatly affect the documentation of the economic impact of mastitis. Therefore, production losses and expenditure related to mastitis in other developing countries and Africa are underestimated and miscalculated [15]. Also, different countries apply distinct methodologies to calculate economic losses due to mastitis, making it difficult to compare [15]. An estimate of the economic impact of mastitis for 3 countries is presented in Table 1. Meanwhile, a few studies in Nigeria such as Moru et al. [37] have attempted to estimate the economic loss associated with mastitis. 
Table 1 Estimated costs due to bovine mastitis in some developing countries [15]

\begin{tabular}{|c|c|c|c|c|c|c|c|}
\hline Area & Milk loss (\%) & Cost $(\$)^{a}$ & Method(s) & Mastitis & $\begin{array}{l}\text { Production } \\
\text { system }\end{array}$ & Period & Reference \\
\hline Ethiopia & 5.6 & 38 per cow & $\begin{array}{l}\text { Production losses due to } \\
\text { sub-clinical mastitis per } \\
\text { subsystem level }\end{array}$ & CM \& SM & $\begin{array}{l}\text { Urban, Peri- } \\
\text { urban and } \\
\text { dairy herds in } \\
\text { secondary towns }\end{array}$ & 2005 & [38] \\
\hline Madagascar & $\mathrm{N} / \mathrm{A}$ & 188 per cow & $\begin{array}{l}\text { Financial loss due to CM } \\
\text { per cow }\end{array}$ & $\mathrm{CM}$ & Peri-urban & 2004 & [39] \\
\hline India & 17.5 & $\begin{array}{l}\text { CM }=91 \text { (cows) and } 75 \\
\text { (buffaloes);SM=192 } \\
\text { (cows)and } 154 \\
\text { (buffaloes) }\end{array}$ & $\begin{array}{l}\text { Milk losses/ animal/ } \\
\text { lactation; economic loss due } \\
\text { to reduced milk production; } \\
\text { Cost of milk discarded due to } \\
\text { CM/animal }\end{array}$ & $C M \& S M$ & $\mathrm{~N} / \mathrm{A}$ & $\begin{array}{l}1962, \\
1994\end{array}$ & {$[40,41]$} \\
\hline
\end{tabular}

$\$=$ cost estimates calculated in US dollars; $C M=$ clinical mastitis; $S M=$ sub-clinical mastitis; $N / A=$ not applicable

All over the country, reports of mastitis prevalence in livestock vary. Similarly, the methods for detection and identification of pathogens associated with sub-clinical mastitis have not been uniform but microscopy has been commonly applied. Other pathogen and disease diagnostic techniques readily employed are the culture method, California mastitis test (CMT), rapid field catalase test (RFCT), and the latex agglutination test (LAT); while data from polymerase chain reactions has been scarce and recent. Furthermore, the physical examination of livestock udders has been employed for the diagnosis of clinical mastitis (Table 2). Over the years, data on the following livestock (cattle, sheep, and goat) positive for mastitis are thus documented (Table 2).

In Nigeria, livestock rearing is a major occupation and serves as a source of livelihood. The product and value chain from livestock processing meets different human needs, meanwhile, mastitis threatens its economic potentials.

More than 140 species of pathogenic bacteria (including Mycoplasma), in addition to fungi, algae and viruses are known to cause clinical and sub-clinical mastitis [66]. Staphylococcus aureus, Escherichia coli, Staphylococcus epidermidis, Streptococcus agalactiae, Klebsiella pneumonia, and Pasteurella spp are the common etiological agents causing mastitis in livestock [2, 7, 54]. Surveyed areas positive for mastitis with prevalence data over the years (1990-2020) are respectively presented in Fig. 1 and Table 2. Similarly, S. aureus and E. coli are mainly responsible for mastitis in cattle and goats with a higher infection rate in the northern than in the southern region of the country (Table 2). The susceptibility of different breeds of goat has been reported $[55,63]$.

Of the 36 states and Abuja, we could only access mastitis data in livestock from 14 states (see Fig.1, Table 2).
Interpreting this with respect to the landmass of Nigeria, a survey on the livestock population in the different states is largely insufficient. Data analysis on livestock (cattle, sheep and goat) mean prevalence by zone using (CMT, RFCT and LAT) estimates the following: North-West $(30.2 \% \pm 24.2 \%)$, North-East (35.8\% $\pm 24.8 \%)$, North-Central $(43.7 \% \pm 14.4 \%)$, South-East $(26.7 \% \pm 35.2 \%)$, South-South $(30.2 \% \pm 0 \%)$ and South-West $(13.1 \% \pm 18.2 \%)$. Furthermore, in mastitis positive livestock, mean prevalence of $S$. aureus was $30.8 \%$, S. agalactiae (11.9\%), S. epidermidis (11.6\%), and K. pneumonia (4.5\%). Also, co-infection of mastitis (3.31\%) with Tuberculosis (4.2\%), Fascioliasis (8\%), Streptothricosis (3.15\%) and worms (1.5\%) has been reported [63]. Among the sampled livestock (cattle, sheep, and goats), the overallmean infection rate for goats $(38.1 \pm 21.9 \%)$ was higher than cattle $(26.5 \pm 22.3 \%)$ and sheep $(20.7 \pm 23.6 \%)$. Similarly, among livestock (cattle, sheep, and goats), the sub-clinical form of mastitis infection is higher than clinical mastitis with $(32.6 \%$ and $24.8 \%)$ respectively. The high infection rate in goats by Staphylococcal mastitis has been documented [56]. Public food safety is being threatened by the constant prevalence of $S$. aureus intramammary infection. However, subclinical mastitis is more difficult to detect because the signs are not readily obvious. Also, the absence of overt manifestation contributes to the challenge for its diagnosis in dairy animal management and in veterinary practices [13]. A high percentage of livestock in this report were infected with subclinical mastitis. Furthermore, subclinical mastitis has been reported to be 15 or 40 times more prevalent than the clinical form and with a longer duration of infection [6]. This is of great concern as the subclinically affected livestock remain a source of infection to herds [67]. Given the different pathogens tied to the cause of mastitis, and based on the reports by [68-71] on the negative 
Table 2 Prevalence of Mastitis in livestock across the states and zones in Nigeria

\begin{tabular}{|c|c|c|c|c|c|c|}
\hline Zones & Location & Number Examined & Prevalence (\%) & Method & Livestock Type & Reference \\
\hline \multirow[t]{12}{*}{ North-West } & Kaduna & 147 & 19.7 & PEM, CMT & Cattle & {$[42]$} \\
\hline & Kaduna & 360 & 26.9 & CMT & Cattle & {$[43]$} \\
\hline & Kaduna & 386 & 60.1 & СMT & Goat & [44] \\
\hline & Kaduna & 147 & 8.1 & $\mathrm{CM} / \mathrm{PCR}$ & Cattle & [45] \\
\hline & Kaduna & 300 & 29.7 & СMT & Cattle & [46] \\
\hline & Kaduna & 42 & 31 & CMT & Cattle & {$[47]$} \\
\hline & Kaduna & 390 & 7.17 & LAT & Cattle & [48] \\
\hline & Kaduna, Kano, Kastina & 900 & 10.2 & PEM & Goat & [49] \\
\hline & Sokoto & 88 & 10.23 & PEM & Cattle, Sheep, Goat & {$[50]$} \\
\hline & Sokoto & 300 & 85.33 & CMT & Cattle & [51] \\
\hline & Sokoto & 100 & 52 & CM & Cattle & [52] \\
\hline & Zamfara & 263 & 21.6 & RFCT & Goat & [53] \\
\hline \multirow[t]{6}{*}{ North-East } & Bauchi & 122 & 47.5 & PEM, CMT & Goat & [54] \\
\hline & Bauchi & 348 & 28.1 & PEM, CMT & Sheep, Goat & [55] \\
\hline & Borno & 300 & 17 & PEM & Goat & {$[56]$} \\
\hline & Borno & 81 & 70.3 & PEM & Goat & {$[20]$} \\
\hline & Borno & 5000 & 2.1 & PEM & Cattle & [57] \\
\hline & Borno & 206 & 50 & PEM & Goat & [58] \\
\hline \multirow[t]{4}{*}{ North-Central } & Plateau & 51 & 63.7 & PEM & Cattle & [59] \\
\hline & Plateau & 85 & 30.5 & СMT & Cattle & {$[60]$} \\
\hline & Plateau & 16 & 43.7 & PEM, CM & Cattle & {$[61]$} \\
\hline & Plateau & 65 & 36.9 & PEM, CMT & Goat & [55] \\
\hline \multirow[t]{3}{*}{ South-East } & Enugu & 58 & 67.24 & CMT & Goat & [62] \\
\hline & Imo & 8615 & 9.7 & PEM & Cattle, Sheep, Goat & {$[30]$} \\
\hline & Imo & 327000 & 3.3 & PEM & Cattle, Sheep, Goat & {$[63]$} \\
\hline South-South & Edo & 63 & 30.2 & PEM, CMT & Goat & [55] \\
\hline \multirow[t]{2}{*}{ South-West } & Oyo & 411 & 26 & CMT & Cattle & [64] \\
\hline & Ogun, Lagos & 641224 & 0.22 & CCF & Cattle & [65] \\
\hline
\end{tabular}

PEM = Physical Examination Method; CMT = California Mastitis Test; PCR = Polymerase Chain Reaction; LAT = Latex Agglutination Test; RFCT $=$ Rapid Field Catalase Test.

effects of mastitis on the African economy, it is clear that mastitis is a complex disease. However, understanding its occurrence; by having a near accurate prevalence picture in Nigeria through the survey of the 36 states using a more sensitive and species-specific method, the related risk, and the pathogens involved are fundamental elements in developing a control program.

\subsection{Diagnosis}

There are many diagnostic techniques available for the detection of mastitis. The diagnosis of clinical mastitis is less complex, because of the apparent signs, including swollen quarter/udder and poor milk quality [72]. Meanwhile, subclinical mastitis cannot be visually detected and requires the use of diagnostic methods.

The traditional available diagnostic method such as the California Mastitis Test (CMT) and / or Somatic Cell Count (SCC) have aided early detection under field conditions
$[73,74]$. CMT determines SCC, and has been used as a cowside indicator test for the diagnosis of subclinical mastitis. The proportion of each somatic cell type (macrophages, lymphocytes, erythrocytes, and epithelial cells) depends on the infection rate of the gland $[75,76]$. In infection-free udders, white blood cells constitute a third of cells, but during infection the white blood cells proportion may reach 99\%. Thus, SCC can show the existence and extent of damage caused by pathogenic species to udder tissue or malfunctioning of milking equipment and, therefore, safeguard milk quality. In Nigeria, the acceptable limit for SCC is set at $<10,000 \mathrm{cfu} / \mathrm{ML}$ for raw milk of good quality, this limit is in accordance with those proposed by $[64,77]$. In addition, the standard SCC and BSCC of good quality fresh milk from a healthy cow is between $<100,000$ cells per $\mathrm{mL}$ and not greater than 500,000 cells per Ml [77]. However, CMT is relatively insensitive and can generally not detect SCC below 350 to 400,000 cells per mL. Furthermore, a CMT will show a high score in recently fresh cows and in cows at the end of lactation just before dry-off; these cases should not 
be over-interpreted as a sign of subclinical mastitis. Also, a CMT is elevated in secretions from cows with decreased milk production due to illness. For example, cows observing peak lactation that become acutely ill due to traumatic reticuloperitonitis may have milk production plummet acutely. Meanwhile, if these cows do not have mastitis on normal udder palpation and strip plate evaluation, the CMT result will indicate positive. The high CMT scores depict a failure of fluid milk production to dilute the somatic cells [78]. This report has clearly outlined the current mastitis diagnostic techniques employed in Nigeria (Table 2), these diagnostic approaches are the known traditional method and the limitation of the sensitivity of some this method may have largely influence the diagnostic outcome. In addition, PCR was only used in only one study (Table 2) conducted by Makolo et al. [45].

Other general tests to detect mastitis include the bacterial culture of milk, electrical conductivity, $\mathrm{pH}, \mathrm{NaOH}$ (white side test), lactate dehydrogenase, measurement of $N$-acetyl-b-D-glucosaminidase, and milk enzyme-linked immunosorbent assay in addition to polymerase chain reaction (PCR) assay [72]. Various PCR assays, as well as multiplex conventional and real-time PCR, have been designed for the detection of mastitis pathogens including Staphylococcus spp, E. coli, M. bovis, S. agalactiae and Enterococcus spp [25, 79-81]. However, Zadoks et al., [82] gave a detailed report on the background of the molecular epidemiology of mastitis pathogens, particularly at the sub-species level, with relevance to public health. The emergence of the loop-mediated isothermal amplification method, which is another nucleic acid amplification technique [83], has led to the development of assays for the detection of Staphylococcus spp, E. coli, M. bovis, S. agalactiae and Enterococcus spp [25, 84-87]. Also, proteomics-based detection, biochips, and biosensors are molecular biological techniques developed for the diagnosis of bovine mastitis [73]. Therefore, an inventory of diagnostic techniques exists can be engaged as the first line of detection from milk samples in Nigeria. The selection of technique(s) with the most desirable attributes (e.g. most reliable, relevant, and rapid) to enhance detection and downstream analyses are the major challenge.

\subsection{Treatment}

The involvement of a high number of different mastitis pathogens remains a challenge towards developing effective mastitis therapy. S. aureus is the most occurring species in livestock as a result of its resistance mechanisms, such as the formation of abscesses within udder or evading antibiotics by residing inside macrophages, therefore escaping antibiotics circulating in the bloodstream [25, 88]. Moreover, the ability of some strains of $S$. aureus to exist as latent bacteria within a cavity as well as reactivating growth when the conditions are favorable has been documented [88]. Furthermore, the presence of planktonic and biofilm growth tends to complicate treatment. The resistance or evasion of antibiotics, coupled with latency have striking implications for treatment and costs. These characteristics are significant to the success of $S$. aureus as a mastitic pathogen prevailing in Nigeria. Similarly, treatment is complicated when co-infection exists as co-infecting pathogens can interact with one another via the host immune system.

In Nigeria, the antibiotics of choice for the treatment of mastitisincludeCefoxitin, Penicillin G, Ampicillin, Amoxicillinclavulanic acid, Ceftriaxone, Vancomycin, Gentamicin, Kanamycin, Erythromycin, Tetracycline, Ciprofloxacin, Nitrofurantoin, Trimethoprim-sulfamethoxazole, and Chloramphenicol. Also, sensitivity and major resistance of $S$. aureus and other mastitis pathogens to these antibiotics have been reported $[44,46,58,60]$.

Presently, there is no universal approach for treating mastitis albeit treatment recommendation due to the extent of deteriorating udder health [88]. Meanwhile, the exploration of phages as an alternative therapy in South Africa has been an interesting development [68, 89]. Numerous benefits could be derived from the use of phages some of which include host specificity, ease of isolation and propagation, reduced toxicity, prolonged shelf life, and presence in the same environment as their bacterial hosts [25]. Thus, problems such as drug resistance, high cost of treatment, and the need to continuously develop a hostspecific antimicrobial can be eliminated. This is because phages tend to evolve with the target host. Nevertheless, it is no doubt that bacteria could create mechanisms to avoid attack and killing by bacteriophages. Bacteria may avoid detection by secreting enzymes that target phages' receptors on the cell wall surface or altering the specificity of phages. Currently, potential bacteriophage therapy is being tailored to combat $S$. aureus given its dominance as an etiological agent in bovine mastitis $[68,89]$. As antibiotic-resistant is not limited to $S$. aureus, the application of phage therapy should be expanded to accommodate other pathogens.

\section{Conclusion}

More studies are required for reliable diagnosing and treating mastitis, as well as estimating the resulting economic impact in Nigeria. Culture-based techniques allow for strain isolation from field samples, molecular 
genetic techniques no doubt offer a rapid, specific, and sensitive detection profile for mastitis. Nonetheless, Nigeria can benefit from developing a clear policy across the state in the geopolitical zones regarding diagnosis. Such a policy should stress the use of rapid techniques as the first line of diagnosis for suspected cases or be applied routinely for confirmation and testing at reference centers. As indicated in this report the prevalence of subclinical mastitis is higher than clinical. The dominance of this form of mastitis is of great concern, as it leads to antimicrobial resistance seen in most mastitis-causing pathogens and is the most damaging and costly as early detection is difficult. Thus, this review has highlighted the prevalence of mastitis across the states and zones in Nigeria, and should serve as a template to advance subsequent analyses as well as a wakeup call to begin a rigorous stepwise process towards the diagnosis and management of mastitis in Nigeria. As sub-clinical mastitis is common in all livestock and indicated with elevated SCC, it is recommended that there be clear communication regarding SCCs adoption for healthy udder in Nigeria. It is paramount to address the case of accuracy when applying SCC to detect mastitis as it will aid farmers through effective administration of antimicrobials therapy.

Only 14 states of Nigeria partially report cases of mastitis in livestock, while the remaining 22 states and Abuja lag behind. This is a small number compared with other countries in Africa. Furthermore, if estimates of milk losses and costs associated with the disease are not well documented, this would delay the planning of control strategies. Undoubtedly, collaborations between the dairy industry, scientific community, and economists, would culminate in better monitoring of the disease impact. However, farmers should engage in regular screening for clinical and subclinical mastitis in other to manage direct and indirect losses. Furthermore, standard for the diagnoses of mastitis in Nigeria using molecular techniques should be implemented, in the same vein, workshops and seminars with practical hands-on training to educate all stakeholders in the livestock industry should be provided as this would go a long way in arming stakeholders with the right tool to diagnose mastitis using molecular techniques as well as using contemporary recommended management standards to monitor, manage or control the spread of the disease.

Authors contribution: $\mathrm{OHA}$ and $\mathrm{ROH}$ conceived and designed the review. COO, GOO, and LIA analyzed the data. All authors interpreted the data, revised the manuscript and approved the final version.

Conflict of interest: Authors state no conflict of interest

\section{References}

[1] Rinaldi M, Li RW, Capuco AV. Mastitis associated transcriptomic disruptions in cattle. Vet Immunol Immunopathol. 2010 Dec;138(4):267-79.

[2] Contreras A, Sierra D, Sanchez A, Corrales JC, Marco JC, Paape MJ, et al. Mastitis in small ruminants. Small Rumin Res. 2007;68(1-2):145-53.

[3] Sori H, Zerihun A, Abdicho S. Dairy cattle mastitis in and around Sebeta, Ethiopia. J Appl Res Vet Med. 2005;3:332-8.

[4] Awale MM, Dudhatra GB, Avinash M, Chauhan BN, Kamani DR, Modi CM, et al. Bovine mastitis: A threat to the economy. Open Access Reports. Online (Bergh). 2012;1:295.

[5] FMARD. Animal population data. Federal Ministry of Agriculture and Rural Development; 2017.[ [cited $2020 \mathrm{Apr}]]$.

[6] Seegers H, Fourichon C, Beaudeau F. Production effects related to mastitis and mastitis economics in dairy cattle herds. Vet Res. 2003 Sep-Oct;34(5):475-91.

[7] Ariffin SM, Hasmadi N, Syawari NM, Sukiman MZ, Faiq TA, Chai MH, et al. Ghazali MF. Prevalence and antibiotic susceptibility pattern of Staphylococcus aureus, Streptococcus agalactiae and Escherichia coli in dairy goats with clinical and subclinical mastitis. Journal of Animal Health Production. 2019;7(1):32-7.

[8] Sarker H, Samad MA. Udder-halve-wise comparative prevalence of clinical and subclinical mastitis in lactating goats with their bacterial pathogens and antibiotic sensitivity patterns in Bangladesh. Bangl. J Vet Med. 2011;9:137-43.

[9] Dasohari A, Kandula S. Mastitis in goats-diagnosis and management. International Journal of Applied Bioscience. 2017;5(6):448-51.

[10] Omotosho AB, Abiodun BJ. A numerical study of moisture build-up and rainfall over West Africa. Metrol Apl. 2007;14(3):209-25.

[11] Ogungbenro SB, Morakinyo TE. Rainfall distribution and change detection across climatic zones in Nigeria. Weather Clim Extrem. 2014;5-6:1-6.

[12] Batavani RA, Asri S, Naebzadeh H. The effect of sub-clinical mastitis on milk composition in dairy cows. Majallah-i Tahqiqat-i Dampizishki-i Iran. 2007;8:205-11.

[13] Kivaria FM. (2006). Epidemiological studies on bovine mastitis in smallholder dairy herds in the Dar es Salaam Region, Tanzania (Phd thesis). Utrecht University, The Netherlands.

[14] Radostis OM, Gay CC, Blood DC, Hinchkliff KW. Veterinary Medicine: A Textbook of the Disease of Cattle, Sheep, Pigs, Goats and Horses. 9th ed. ELBS \&Baillier Tindall; 2000. pp. 563-660.

[15] FAO. Impact of mastitis in small scale dairy production systems. Animal Production and Health Working, 2014; Pp 13, Rome. [Available online at www.fao.org/3/a-i3377e].

[16] Hogan SJ, Gonzales RN, Harmon JR, Nickerson SC, Oliver SP, Pankey JW, et al. Laboratory handbook on bovine mastitis. Published by National Mastitis Council, Inc., Verona, WI 53593, USA, 1999.

[17] Nicholas RA, Fox LK, Lysnyansky I. Mycoplasma mastitis in cattle: to cull or not to cull. Vet J. 2016 Oct;216:142-7. 
[18] Al-Farha AA, Hemmatzadeh F, Khazandi M, Hoare A, Petrovski $\mathrm{K}$. Evaluation of effects of Mycoplasma mastitis on milk composition in dairy cattle from South Australia. BMC Vet Res. 2017 Nov;13(1):351.

[19] Fox LK, Hancock DD, Mickelson A, Britten A. Bulk tank milk analysis: factors associated with appearance of Mycoplasma sp. in milk. J Vet Med B Infect Dis Vet Public Health. 2003 Jun;50(5):235-40.

[20] Egwu GO, Ameh MM, Aliyu FD. Caprine mycoplasmal masititis in Nigeria. Vet Arh. 1999;69:241-50.

[21] Waites KB, Lysnyansky I, Bébéar CM. Emerging antimicrobial resistance in mycoplasmas of human and animals. In: Browning GF, Citti C, editors. Mollicutes: Molecular Biology and Pathogenesis. Norfolk, England: Caister Academic Press; 2014. pp. 289-322.

[22] McAuliffe L, Ellis RJ, Miles K, Ayling RD, Nicholas RA. Biofilm formation by mycoplasma species and its role in environmental persistence and survival. Microbiology (Reading). 2006 Apr;152(Pt 4):913-22.

[23] Fox LK. Mycoplasma mastitis: causes, transmission, and control. Vet Clin North Am Food Anim Pract. 2012 Jul;28(2):225-37.

[24] Nicholas RA, Ayling RD, McAuliffe L. Vaccines for Mycoplasma diseases in animals and man. J Comp Pathol. 2009 Feb-Apr;140(2-3):85-96.

[25] Motaung TE, Petrovski KR, Petzer IM, Thekisoe O, Tsilo TJ. Importance of bovine mastitis in Africa. Anim Health Res Rev. 2017 Jun;18(1):58-69.

[26] Sudhan NA, Sharma N. Mastitis- An important production disease of dairy animals. SMVS' Dairy Year Book; 2010.

[27] Joshi S, Gokhale S. Status of mastitis as an emerging disease in improved and periurban dairy farms in India. Ann N Y Acad Sci. 2006 Oct;1081(1):74-83.

[28] Dego OK, Tareke F. Bovine mastitis in selected areas of southern Ethiopia. Trop Anim Health Prod. 2003 Jun;35(3):197-205.

[29] Kawu MU, Umoh JU, Adekeye JO, Kwanashie G. Prevalence and seasonal variation in the occurrence of clinical mastitis in small ruminants in Zaria, Nigeria. Proc. 29th AGM of Nigeria Veterinary Medicine Association Kaduna 27th-30th October. 1992. P 131-135.

[30] Okoli IC, Opara MN, Iheukwumere E, Herbert U. Analysis of abattoir records for Imo State, Nigeria from 1995-1999 IV: incidence of mastitis among cattle, sheep and goats. J Agric Soc Res. 2006;6:66-72.

[31] FAO. Review of the livestock/meat and milk value chains and policy influencing them in Nigeria. 2016; Pp 36.

[32] FAO. The future of livestock in Nigeria. Opportunities and challenges in the face of uncertainty, Rome, 2019; [Available online at http://www.fao.org/faostat/en/\#data/TP].

[33] Bradley A. Bovine mastitis: an evolving disease. Vet J. 2002 Sep;164(2):116-28.

[34] Petrovski KR, Heuer C, Parkinson TJ, Williamson NB. The incidence and aetiology of clinical bovine mastitis on 14 farms in Northland, New Zealand. N Z Vet J. 2009 Apr;57(2):109-15.

[35] Costello S. Consultant guide to economics of mastitis, (2007). [Available online at www.smartstock-usa.com].

[36] Viguier C, Arora S, Gilmartin N, Welbeck K, O’Kennedy R. Mastitis detection: current trends and future perspectives. Trends Biotechnol. 2009 Aug;27(8):486-93.
[37] Moru NH, Umoh JU, Maikai BV, Barje PP, Amuta P. Milk yield losses and cost of clinical mastitis in Friesian and Bunaji crossbred dairy cows in Zaria, Nigeria. Sokoto J Vet Sci. 2018;16(2):28-34.

[38] Mungube EO, Tenhagen BA, Regassa F, Kyule MN, Shiferaw $\mathrm{Y}$, Kassa T, et al. Reduced milk production in udder quarters with subclinical mastitis and associated economic losses in crossbred dairy cows in Ethiopia. Trop Anim Health Prod. 2005 Aug;37(6):503-12.

[39] Ravaomanana J, Rasambainarivo JH, Perrot A, Razafiarison O, Rakotonindra S. Mastitis in dairy cows and its economic impact on smallholder production in highland zones of Madagascar. In: proceedings of the 11th International Conference of the Association of Institutions for Tropical Veterinary Medicine, and the 16th Veterinary Association of Malaysia Congress 23-27, 2004; 94-95

[40] Dhanda MR, Sethi MS. Investigation of mastitis in India. New Delhi: Indian Council of Agricultural Research; 1962.

[41] Singh PJ, Singh KB. A study of economic losses due to mastitis in India. Indian J Dairy Sci. 1994;47:265-72.

[42] Makolo D, Suleiman AB, Olonitola OS, Bello M, Ahmadu I, Awulu FO, et al. Prevalence of mastitis in lactating bovines and associated coliforms among selected pastoral herds in parts of Kaduna State, Nigeria. Academic Journal of Life Sciences. 2019;5(51):1-9.

[43] Umaru GA, Kwaga JK, Bello M, Raji MA, Maitala YS. Occurrence of bovine mastitis and isolation of Staphyloccocus species from fresh cow milk in settled Fulani herds in Kaduna State, Nigeria. Bayero J Pure Appl Sci. 2017;10(1):259-63.

[44] Udoh EK, Kwaga JK, Umoh JU, Raji MA. Occurrence of mastitis and methicillin resistance Staphylococcus aureus in goats in Zaria, Kaduna State, Nigeria. Niger Vet J. 2019;40(2):164-77.

[45] Makolo D, Suleiman AB, Olonitola OS, Bello M, Ahmadu I. genotypic identification of coliforms isolated from cases of subclinical mastitis among pastoral herds in parts of Kaduna State, Nigeria. Afr J Clin Exp Microbiol. 2020;21(2):114-22.

[46] Mbuk EU, Kwaga JK, Bale JO, Boro LA, Umoh JU. Coliform organisms associated with milk of cows with mastitis and their sensitivity to commonly available antibiotics in Kaduna State, Nigeria. J Vet Med Anim Health. 2016;8(12):228-36.

[47] Umoh VI, Adesiyun AA, Comwalk NE. Enterotoxigenicity of Staphylococci isolated from raw milk obtained from settled and nomadic herds around Zaria, Nigeria. Revue d’ Elevage et de. Médecine Vétérinaire des. Pays tropicaux, 1990; 43: 43-47.

[48] Akange EN, Kwanashie CN, Bisalla M, Useh NM, Ngbede EO. Evidence of Cryptococcosis in cattle in Zaria Kaduna State, Nigeria. Vet World. 2013;6(2):64.

[49] Ameh JA, Addo PB, Adekeye JO, Gyang EO. Prevalence of clinical mastitis and of intramammary infecctions in Nigeria goats. Prev Med. 1993;17:41-6.

[50] Umaru MA, Adeyeye AA, Abubakar A, Garba HS. Retrospective analysis of disease conditions among reproductive domestic ruminants in Sokoto, Nigeria. Anim Res Int. 2009;6(1):946-8.

[51] Shittu A, Abdullahi J, Jibril A, Mohammed AA, Fasina FO. Sub-clinical mastitis and associated risk factors on lactating cows in the Savannah Region of Nigeria. BMC Vet Res. 2012 Aug;8(1):134.

[52] Junaidu AU, Salihu MD, Tambuwal FM, Magaji AA, Jafaru S. Prevalence of mastitis in lactating cows in some selected commercial dairy farms in Sokoto metropolis. Advances in Applied Research. 2011;2:290-4. 
[53] Tanimomo BK, Hena SA, Ngbede EO, Tarhyel R, Owoleke OE. Prevalence of mastitis in goat herds in some northwestern villages in Nigeria. Scientific Journal of Veterinary Advances. 2012;1:52-6.

[54] Danmallam FA, Pimenov NV. Study on prevalence, clinical presentation, and associated bacterial pathogens of goat mastitis in Bauchi, Plateau, and Edo states, Nigeria. Vet World. 2019 May;12(5):638-45.

[55] Danmallam FA, Pimenov NV, Ngulukun SS, Mwankon SE. Prevalence and bacterial etiology of mastitis in small ruminants in Toro local government area, Bauchi State, Nigeria. Russ J Agric Soc-Econ Sci. 2018;7(7):341-5.

[56] Ameh JA, Tari IS. Observation on the prevalence of caprine mastitis in relation to predisposing factors in Maiduguri. Small Rumin Res. 2000;35(1):1-5.

[57] Ameh JA, Edegbe NT, Zaria LT. Prevalence of bovine mastitis in Maiduguri Borno State, Nigeria. Vet Arh. 1999;69:87-95.

[58] Egwu GO, Zaria LT, Onyeyili PA, Ambali AG, Adamu SS, Birdling M. Studies on the microbiological flora of caprine mastitis and antibiotic inhibitory concentrations in Nigeria. Small Rumin Res. 1994;14(3):233-9.

[59] Ebojei CO, Davou GC, Salman BS, Mosimabale VO. Prevalence of mastitis among dairy cattle in Kanam Local Government Area of Plateau State, Nigeria. Hum Vet Med Int J Bioflux Soc. 2010;2:77-81.

[60] Suleiman AB, Kwaga JK, Umoh VJ, Okolocha EC, Muhammed M, Lammler C, et al. Macro-restriction analysis of Staphylococcus aureus isolated from subclinical bovine mastitis in Nigeria. Afr J Microbiol Res. 2012;6:6270-4.

[61] Anueyiagu KN, Isiyaku AW. Isolation, identification of Staphylococcus aureus from bovine milk and its antibiotics susceptibility. Int J Livest Prod. 2015;6(6):74-7.

[62] Ugochukwu IC, Anyaoha CO, Aneke Cl, Idoko SI, Ugwu JU, Ughamba KT, et al. Aerobic bacteria pathogens associated with caprine mastitis in Nsukka Area of Enugu State. Bio-Research. 2017;15(1):980-7.

[63] Okoli CG, Okoli IC, Okorondu UV, Opara MN. Environmental and public health issues of animal food products delivery system in Imo State, Nigeria. Online J Health Allied Sci. 2006;2:1-11.

[64] Olufemi O, Adesola A, Uzo O, Yemi O. Bulk tank somatic cell count and associated microbial quality of milk from selected dairy cattle herds in Oyo State, Nigeria. Italian Journal of Food. 2018;7(2):95-100.

[65] Cadmus SI, Adesokan HK. Causes and implications of bovine organs/offal condemnations in some abattoirs in Western Nigeria. Trop Anim Health Prod. 2009 Oct;41(7):1455-63.

[66] Petrovski KR, Williamson NB, Lopez-Villalobos N, Parkinson TJ, Tucker IG. Culture results from milk samples submitted to veterinary diagnostic laboratories from August 2003 to December 2006 in New Zealand. N Z Vet J. 2011 Nov;59(6):317-22.

[67] Islam MA, Islam MZ, Islam MA, Rahman MS, Islam MT. Prevalence of sub-clinical mastitis in dairy cows in selected areas of Bangladesh. Bangladesh J Vet Med. 2011;9(1):73-8.

[68] Basdew IH, Lang MD. Biological control of bovine mastitis using bacteriophage therapy. In: A Mendez-Vilas (ed.) Science against microbial pathogens: Communicating Current Research and Technology Advances. Singapore: Formatex, 2011; (1): 386-393.

[69] Saidi R, Khelef D, Kaidi R. Subclinical mastitis in cattle in Algeria: frequency of occurrence and bacteriological isolates. Journal of the South African Veterinary Association, 2013; 84: Art. \#929, 5 pages. https://doi.org/10.4102/jsava.v84i1.929.
[70] Gitau GK, Bundi RM, Vanleeuwen J, Mulei CM. Mastitogenic bacteria isolated from dairy cows in Kenya and their antimicrobial sensitivity. Journal of the South African Veterinary Association 2014; 85: 01- 08. https://doi.org/10.4102/jsava. v85i1.950.

[71] Kassa F, Ayano AA, Abera M, Kiros A. Longitudinal study of bovine mastitis in Hawassa and Wendo Genet small holder dairy farms. Global Journal of Science Frontier Research: D Agriculture and Veterinary, 2014; 14: 34-41.

[72] Mahmmod Y. The future of PCR technologies in diagnosis of bovine mastitis pathogens. J Adv Dairy Res. 2013;2:e106.

[73] Deb R, Kumar A, Chakraborty S, Verma AK, Tiwari R, Dhama $\mathrm{K}$, et al. Trends in diagnosis and control of bovine mastitis: a review. Pak J Biol Sci. 2013 Dec;16(23):1653-61.

[74] Duarte CM, Freitas PP, Bexiga R. Technological advances in bovine mastitis diagnosis: an overview. J Vet Diagn Invest. 2015 Nov;27(6):665-72.

[75] Pillai SR, Kunze E, Sordillo LM, Jayarao BM. Application of differential inflammatory cell count as a tool to monitor udder health. J Dairy Sci. 2001 Jun;84(6):1413-20.

[76] Sharma N, Singh NK, Bhadwal MS. Relationship of somatic cell count and mastitis: an overview. Asian-Australas J Anim Sci. 2011;24(3):429-38.

[77] PMO. Grade "A" Pasturized Milk Ordination. U.S. Department of Health and Human Service, Food and Drug Administration, 2009; pp 405.

[78] Moroni P, Nydam DV, Ospina PA, Scillieri-Smith JC, Virkler PD, Waters VR, et al. Disease of the teats and udder. 3rd ed. Rebhun's Diseases of Dairy Cattle; 2018. pp. 389-465.

[79] Shome BR, Das Mitra S, Bhuvana M, Krithiga N, Velu D, Shome $R$, et al. Multiplex PCR assay for species identification of bovine mastitis pathogens. J Appl Microbiol. 2011 Dec;111(6):1349-56.

[80] Hiitiö H, Riva R, Autio T, Pohjanvirta T, Holopainen J, Pyörälä S, et al. Performance of a real-time PCR assay in routine bovine mastitis diagnostics compared with in-depth conventional culture. J Dairy Res. 2015 May;82(2):200-8.

[81] Barbier E, Boschiroli ML, Gueneau E, Rochelet M, Payne A, de Cruz K, et al. First molecular detection of Mycobacterium bovis in environmental samples from a French region with endemic bovine tuberculosis. J Appl Microbiol. 2016 May;120(5):1193-207.

[82] Zadoks RN, Middleton JR, McDougall S, Katholm J, Schukken YH. Molecular epidemiology of mastitis pathogens of dairy cattle and comparative relevance to humans. J Mammary Gland Biol Neoplasia. 2011 Dec;16(4):357-72.

[83] Tomita N, Mori Y, Kanda H, Notomi T. Loop-mediated isothermal amplification (LAMP) of gene sequences and simple visual detection of products. Nat Protoc. 2008;3(5):877-82.

[84] Kato H, Yoshida A, Ansai T, Watari H, Notomi T, Takehara T. Loop-mediated isothermal amplification method for the rapid detection of Enterococcus faecalis in infected root canals. Oral Microbiol Immunol. 2007 Apr;22(2):131-5.

[85] Zhang J, Zhang GH, Yang L, Huang R, Zhang Y, Jia K, et al. Development of a loop-mediated isothermal amplification assay for the detection of Mycobacterium bovis. Vet J. 2011 Mar;187(3):393-6.

[86] Wang D, Wang Y, Xiao F, Guo W, Zhang Y, Wang A, et al. A comparison of in-house real-time LAMP assays with a commercial assay for the detection of pathogenic bacteria. Molecules. 2015 May;20(6):9487-95. 
[87] Bosward KL, House JK, Deveridge A, Mathews K, Sheehy PA. Development of a loop-mediated isothermal amplification assay for the detection of Streptococcus agalactiae in bovine milk. J Dairy Sci. 2016 Mar;99(3):2142-50.

[88] du Preez JH. Bovine mastitis therapy and why it fails. J S Afr Vet Assoc. 2000 Sep;71(3):201-8.
[89] Basdew IH. Biological and molecular characterization of South African Bacteriophages infection against Staphylococcus aureus sub sp. aureus Rosenbach 1884, causal agent of Bovine mastitis. Republic of South Africa: School of Agriculture, Earth and Environmental Sciences, Faculty of Science and Agriculture, University of Kwazulu-Natal, 2012. 